\title{
腹腔鏡下リンパ節郭清におけるフィブリン糊使用による リンパ浮腫並びにリンパ衰胞予防の試み \\ The use of fibrin glue to prevent the formation of lymphedema and lymphocele following laparoscopic lymphadenectomy for gynecologic malignancies.
}

\author{
王子総合病院産婦人科 ${ }^{1}$ \\ 北海道大学大学院医学研究科 生殖 - 発達医学講座産科学分野 ${ }^{2}$ \\ 北海道大学大学院医学研究科 生殖 - 発達医学講座婦人科学分野 ${ }^{3}$ \\ 石本真紀 ${ }^{1}$ 、光部兼六郎 ${ }^{1} 、$ 木川聖美 ${ }^{1}$ 、森脇征史 ${ }^{2}$ 、工藤正尊 ${ }^{3}$ 、野村英司 ${ }^{1}$
}

\section{はじめに}

下肢リンパ浮腫とリンパ震胞は、系統的リンパ 節郭清をその術式に含む婦人科悪性腫瘍手術に付 随して生ずる合併症で、発生率は施設によりさま ざまであるが、傍大動脈〜骨盤リンパ節郭清施行 症例の約10～20\%とする報告が多い ${ }^{1.2)}$ 。郭清によ るリンパ管の損傷や離断によるリンパ夜のうっ滞 がこれらの成因となっており、リンパ液の間質組 織間隙への漏出や貯留がリンパ浮腫を、後腹膜腔 での死腔形成がリンパ囊胞を引き起すと考えられ ている。リンパ浮腫は悪化すると組織内の線維化 を生じ、易感染性となり蜂窩織炎を繰り返す。リ ンパ囊胞の多くは無症候性であるが、時に増大し 感染を伴うと治療を要する場合があり、術後長期 にわたり患者のQOLを損なわせる原因となる。

当科では、手術の低侵襲化と周術期合併症の低 減を目的として、2004年 7 月より傍大動脈リンパ 節ならびに骨盤リンパ節郭清を含む腹腔鏡下婦人 科悪性腫瘍手術を導入した。腹腔鏡下手術であっ ても、その手術内容は基本的に開腹術と同様に行 われるべきであり、われわれは鏡視下での開腹手 術術式の再現に努めている。しかしながら、内視 鏡手術においては、挟鉗・切断・結紮という開腹 手術で一般的に行われる操作に比較的困難を伴う ことがあり、リンパ管の処理が不十分となること で、リンパ浮腫やリンパ襄胞を開腹術より高頻度 に生ずる可能性が予想された。

われわれは、手術終了時に後腹膜腔を閉鎖せず に開放とし、さらにフィブリン糊を噴霧すること で死腔形成を予防して後腹膜腔を完全に腹腔化で きるのではないかと考えた。これにより滲出した
リンパ液は後腹膜腔から腹腔内に移行し、最終的 に腹膜から吸収されることによりリンパ液の貯 留・うっ滞が生じないため、リンパ浮腫ならびに リンパ顀胞が予防される（図 1 )。本稿では、こ の仮説に基づいて腹腔鏡下リンパ節郭清術終了時 に、希釈した大量のフィブリン糊を後腹膜腔に噴 霧することで、リンパ浮腫並びにリンパ襄胞の予 防が可能であるかを検討し、若干の文献的考察を 加えて報告する。

図 1 フィブリン糊によるリンパ節郭清後のリンパ浮腫・リンパ䚻 胞の発症予防機序（仮説）

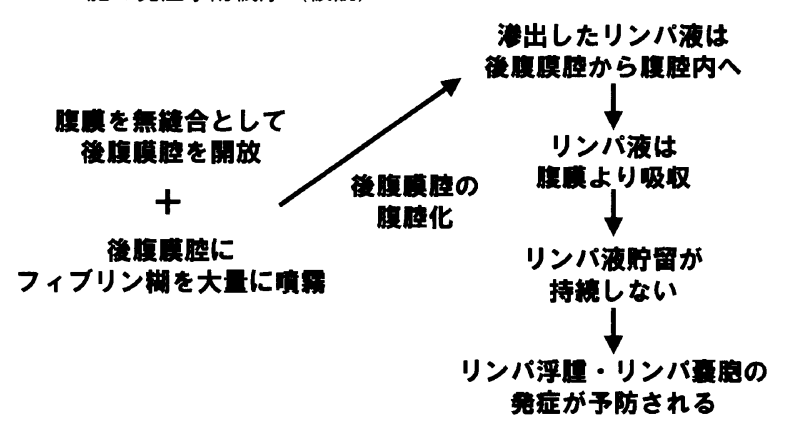

対象と方法

対象は2004年 7 月より 2005 年 4 月までに、当科 で後腹膜リンパ節郭清を術式に含む腹腔鏡下婦人 科悪性腫瘍手術を施行した13例で、その内訳は子 宮頸癌 4 例、子宮体癌 4 例、卵巣癌 3 例、体癌と 卵巣癌の重複癌 2 例であった（表 1 )。これらの 症例についてドレーン抜去までの術後日数、退院 日、リンパ浮腫の有無、リンパ囊胞の有無、貯留 腹水の量を検討した。術後のリンパ浮腫やリンパ 囊胞の発生、腹水量の増減に関しては、理学所 見・CTならびに超音波検査などを用いて評価し た。 
表 1 症例一覧

\begin{tabular}{|c|c|c|c|c|c|}
\hline 症例 & 年数 & 病名 & 進行期 & 腹壻鏡前の治源 & 腹臸鏡術式 \\
\hline 1 & 58 & 㚹䉓癌 & IIIc & & ETH+LND \\
\hline 2 & 53 & 子宮体痍/卿果病 & $\mathrm{la} / \mathrm{lb}$ & $A T H+B S O$ & LND+IFD+ONT \\
\hline 3 & 55 & 子宮体癌 & ib & & ETH+LND \\
\hline 4 & 38 & 卵果虽 & $\| c$ & $\begin{array}{l}\text { LSO+LtPLD } \\
\text { +ONT+APD }\end{array}$ & ETH+RSO+LND+IFD \\
\hline 5 & 46 & 子宮頙癌 (腺癌) & la & conization & ETH+LND \\
\hline 6 & 54 & 卵褁癌 & la & BSO TJ & ETH+LND+IFD+ONT \\
\hline 7 & 48 & 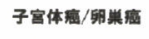 & $\mathrm{la} / \mathrm{lc}$ & $\begin{array}{l}\text { AT }+ \text { BSOAPND } \\
\text { +OMT+APD TJ }\end{array}$ & LND+IFD \\
\hline 8 & 48 & 子宮頻癌 & $\| b$ & & RH+LND \\
\hline 9 & 35 & 卵巣癌 & $\| / c$ & $\begin{array}{l}\text { LSO+OMT } \\
\text { CEP }\end{array}$ & ETH+RSO+LND+IFD+APD \\
\hline 10 & 36 & 子宮䫫富 & $|b|$ & conization & RH+LND \\
\hline 11 & 60 & 子宮体癌 & la & & ETH+BSO+LND+IFD \\
\hline 12 & 38 & 子宮䫓䔄 & $\| b$ & $T P$ & RH+LND \\
\hline 13 & 51 & 子宮体癌 & lb & & ETH+BSO+LND+IFD \\
\hline
\end{tabular}

ATH: Abdominal total hysterectomy ETH: Extended total hysterectomy $\mathrm{RH}$ : Radical hysterectomy LND: Lymph node dissection PLD: Pelvic lymph node dissection IFD: Infundibulo-pelvic ligament dissection BSO: Bilateral salpingo-oophorectomy RSO: Right salpingo-oophorectomy LSO: Left salpingo-oophorectomy OMT: Omentectomy APD: Appendectomy TJ: Taxol+CBDCA TP:

当科における腹腔鏡下婦人科悪性腫瘍手術の内 容は開腹手術と同様であり、子宮頸癌においては 広汎子宮全摘術と下腸間膜動脈レベル以下のリン パ節郭清、子宮体癌と卵巣癌においては拡大子宮 全摘術、両側付属器摘出術、腎血管以下のリンパ 節郭清、卵巣血管摘出術、卵宩癌の場合にはさら に大網・虫垂切除術を加えて施行している。骨盤 リンパ節は全例経腹膜アプローチで郭清を行い、 大腿上リンパ節に関しては、明らかな腫大を認め た場合以外は郭清せずに温存した。郭清操作には おもに電気メス（monopolar）を用い、骨盤リン パ組織の尾側断端はクリッピング・結紮を行わず に電気メスにより焼灼・切断した（図 2 )。傍大 動脈リンパ節の郭清は症例により経腹膜アプロー チと後腹膜アプローチのいずれかを選択して行っ た。傍大動脈リンパ節を含むリンパ組織は尾側よ り頭側へ向かって大動脈より剥離・切除し、頭側 断端は可及的にクリッピングまたは結紮処理して

図 2 骨盤リンパ節郭清 大腿上リンパ節は電気メスで切断した。

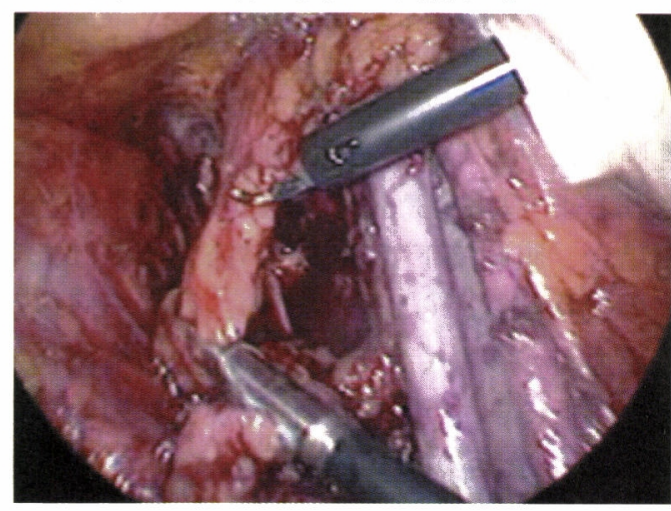

摘出した (図 3 )。

図 3 傍大動脈リンパ節郭清 傍大動脈節頭側断端はクリッピングまたは結紮処理 した。

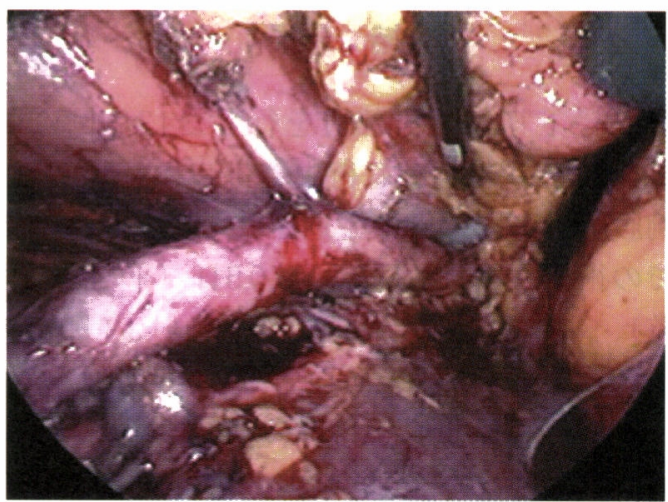

リンパ節郭清終了後、腹膜は縫合せずに後腹膜 腔を開放とし、手術終了時にフィブリン糊（ボル ヒール ${ }^{\circledR}$ ）を剥離血管周囲やリンパ管断端周囲、 後腹膜裏面および断端に十分量噴霧した。フィブ リン糊は、蒸留水で約 4 〜 倍に希釈したものを スプレーセットで使用した（図 4、5）。最後に ペンローズドレーンを開放された左右膀胱側腔に 置き手術を終了した。ドレーンは自然流出として 持続吸引は行わなかった。

なお、特定生物由来製品であるフィブリン糊を

図 4 骨盤底への希䣋フィブリン糊の噴霧 ボルヒール 5 mlを蒸留水で4-6倍に希釈して使用し た。

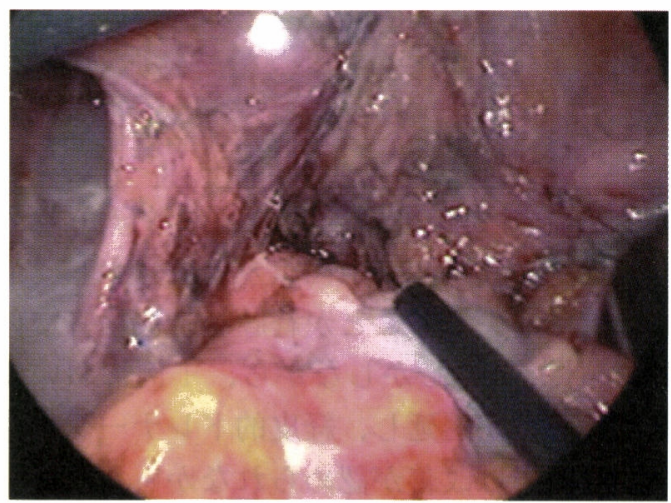

図 5 後腹膜腔への希釈フィブリン糊の隫霧

総腸骨動脈分岐部付近にボルヒール®を噴霧している 様子。

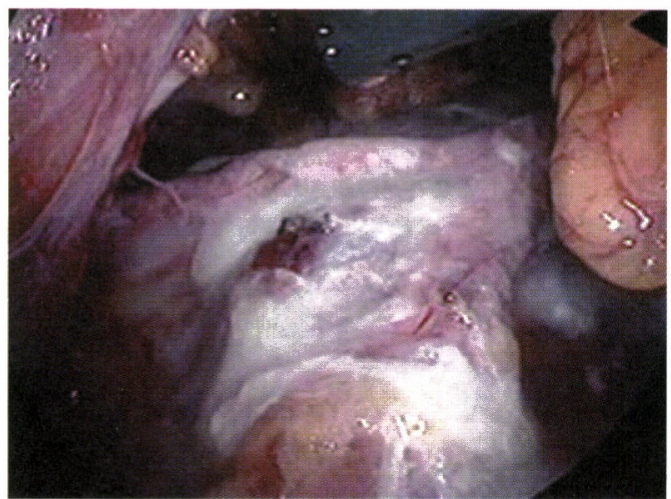


腹腔内の剥離面に使用する必要性と副作用の可能 性などについては術前にインフォームドコンセン トを得ている。

\section{結果}

腹腔鏡下リンパ節郭清を行った 13 症例につい て、開腹が必要となる術中合併症は経験されず、 全例腹腔鏡下で手術は完遂された。ドレーン抜去 までの術後平均日数は5.5 \pm 0.5 日（平均 \pm 標準 䛊差)、入院日数は術後平均 $10.6 \pm 1.7$ 日であっ た。リンパ浮腫は、可逆性のごく軽度のもの (stage $0 /$ latent stageまたはstage 1相当: International Society of Lymphologyによる分類) を 3 例に認めたが治療は不要で、外来での経過観 察中に軽快した。リンパ囊胞は 2 例に認められた が、術後 6 ケ月を経過した時点では 2 例とも自然 消失していることが確認された（表 2 )。

表 2 各症例の術後経過

\begin{tabular}{|c|c|c|c|c|c|}
\hline 症例 & $\begin{array}{c}\text { トレーン拔去 } \\
\text { (術後日数) }\end{array}$ & $\begin{array}{c}\text { 退院日 } \\
\text { (衡後日数) }\end{array}$ & $\begin{array}{c}\text { リンパ䋛腫 } \\
\text { の有栕 }\end{array}$ & $\begin{array}{c}\text { リンバ䚈胞 } \\
\text { の有 }\end{array}$ & その他の合併症 \\
\hline 1 & 4 & 9 & $(-)$ & $(-)$ & \\
\hline 2 & 4 & 21 & $(-)$ & $(+) \rightarrow(-)$ & ポート創部感染 \\
\hline 3 & 4 & 8 & $(-)$ & $(-)$ & 乳黁腹水 $\rightarrow$ 再手術 \\
\hline 4 & 6 & 7 & $(-)$ & $(t) \rightarrow(-)$ & \\
\hline 5 & 7 & 10 & $(-)$ & $(-)$ & \\
\hline 6 & 9 & 9 & $(+) / G r a d e 0-1$ & $(-)$ & \\
\hline 7 & 4 & 8 & $(-)$ & $(-)$ & \\
\hline 8 & 10 & 16 & (t) $/$ Grade $0-1$ & $(-)$ & \\
\hline 9 & 5 & 11 & $(-)$ & $(-)$ & \\
\hline 10 & 5 & 12 & $(-)$ & $(-)$ & \\
\hline 11 & 5 & 10 & $(-)$ & $(-)$ & \\
\hline 12 & 4 & 7 & $(-)$ & $(-)$ & \\
\hline 13 & 5 & 10 & (t) $/$ Grade $0-1$ & $(-)$ & \\
\hline
\end{tabular}

多くの症例で術後一過性の腹水貯留を認めた が、外来での経過観察中に腹水量は減少し、最終 的にはほぼ消失することが経腔超音波検査で確認 された（図6)。しかしながら、1 例において乳 糜腹水の貯留が遷延し、経皮的ドレナージを含む 保存的治療では改善が認められなかったため、術 後 8 週目に再手術を行った。腹腔鏡下において乳 糜腹水の漏出部位は確認されなかったが、腹膜頭 側断端付近・腹膜再生部位にフィブリン糊を噴霧 して手術を終了した。再手術後、乳糜腹水は急速 図 6 貯留腹水量の経時的変化 (症例 5 ) 術後一過性の腹水貯留を認めたが、経時的に減少し最終的 にほぼ消失したことが確認された。

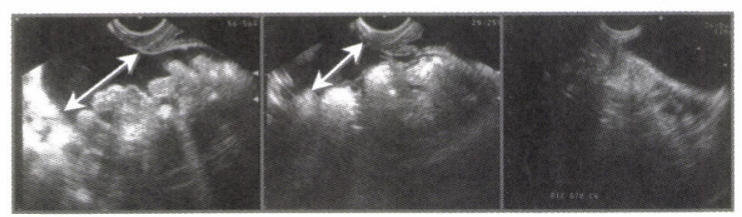

術後2週目

術後6週目
に減少し、現在は腹水の貯留を認めていない。こ の 1 例を含めた全 13 症例について、術後 $5 \sim 15$ ケ 月間の観察期間で治療が必要なリンパ浮腫を認め る症例はなく、無症候性のものを含めてリンパ輁 胞が存続している症例は確認されていない。また、 腹腔鏡下リンパ郭清術 7 ケ月後にSecond look laparoscopyを行った 1 例（症例 4 ）に扔いて骨 盤底を被覆する組織の一部を採取したところ、病 理学的に再生腹膜であることが確認された(図 7 、 8 )。

図 7 リンパ節郭清7ヶ月後の腹腔内所見（症例 4) 腹膜無縫合法で処理された骨盤底は再生した膜様物 で被覆されていた。

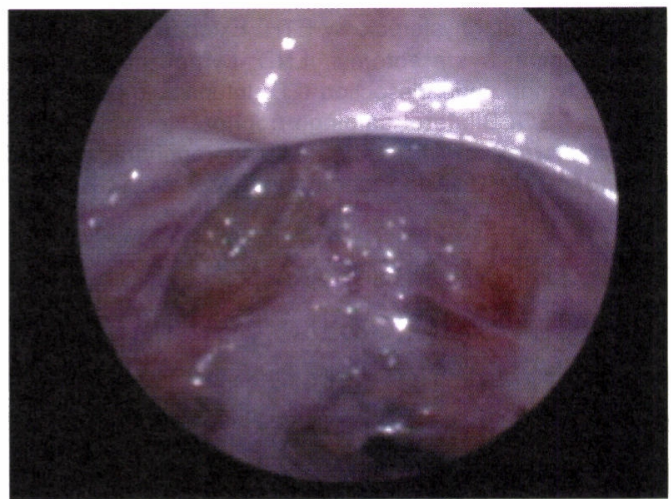

図 8 採取された骨盤底の組織(症例 4)

線維性結合組織の表面を 1 層の扁平化した中皮細胞 が覆っている。

再生した腹膜として矛盾しない病理所見であった。

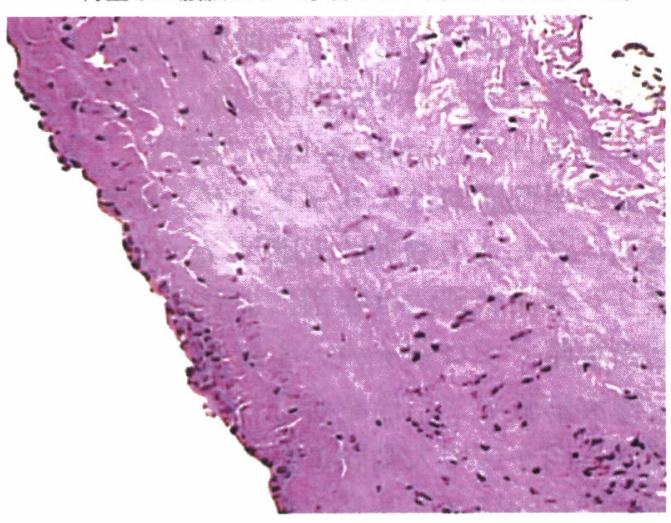

考察

婦人科領域での腹腔鏡下リンパ節郭清術は 1990 年代初頭に初めて報告され ${ }^{3.4)}$ 、現在では婦人科 悪性腫塲に対する治療の選択肢のひとつとして認 識されるようになってきている。開腹手術と比較 した場合、腹腔鏡下でのリンパ節郭清では、手術 時間の延長は認められるものの、術後の回復が早 く、出血量が少なく、イレウスなどの術後合併症 発生率が低く、また、入院日数がより短い等の利 点があり、患者のQOLを高めることが期待され $3^{5.6)}$ 。長期予後に関する検討も近年報告される 
ようになり、従来の開腹術に遜色ない治療成績が 示されている ${ }^{5,78)}$ 。しかしながら、内視鏡下手術 は低侵襲である一方、その手技の困難性や限界、 また潜在的な重症合併症の可能性について常に認 識されていなければならない9)。

今回われわれは、開腹と比較して手術操作に制 限がある腹腔鏡下リンパ節郭清術を導入するに当 たり、術後に生ずるリンパ浮腫・リンパ襄胞の発 症を最小限とするためにいくつかの試みを行っ た。その内容は 1 ）腹膜無縫合による後腹膜腔の 開放、2）後腹膜腔の癒着防止のための大量フィ ブリン糊噴霧、さらに従来から行っている 3 ）頭 側リンパ管断端の可及的なクリッピング／結紮処 理、また2004年12月より追加した 4 ）大腿上リン パ節の温存である。フィブリン糊は高価で大量に 使用することは困難であり、我々は蒸留水で 4 〜 6 倍に希釈して使用することを考案した。これに より、より広い剥離面にフィブリン糊を多量に噴 霧することが可能となり、また結果として組織， 腹膜の間隙に大量にフィブリン塊が存在すること により組織間の癒着防止効果が発揮されるのでは ないかと推測された。今回の検討において、観察 期間は術後 $5 \sim 15$ ケ月と比較的短期であり、また 症例数も少なかったが、リンパ浮腫についてはご く軽度のものが 3 例認められたのみであり、いず れも可逆的かつ一過性のもので、外来での経過観 察で進行・増悪を認めなかった。リンパ囊胞を認 めた 2 例についてもいずれも無症候性で、術後 6 ヶ月以内に消失した。これらの結果より、腹膜無 縫合にフィブリン糊大量噴霧を併用することで、 腹腔鏡下リンパ節郭清後のリンパ浮腫・リンパ襄 胞の発症を低減できる可能性が示唆された。

婦人科領域において腹腔鏡下リンパ節郭清後の リンパ浮腫・リンパ囊胞発症率を詳細に検討した 文献は少ない。Kohlerら ${ }^{6)}$ による傍大動脈リンパ 節または骨盤リンパ節郭清を施行した650症例の 検討では 6 例のリンパ浮腫、 3 例の再手術が必要 なリンパ囊胞、 3 例の乳糜腹水貯留が認められた。 Spirtosら ${ }^{10)}$ は73例中 2 例のリンパ囊胞を報告し、 Nezhatら ${ }^{11)}$ は超音波鏯刀を用いて郭清を行った 100 症例でリンパ囊胞の発症を認めていない。こ れらの結果は報告されている開腹術によるリンパ 襄胞発症率よりも低く ${ }^{1,2,12)}$ 、腹腔鏡下手術の開腹 術に対するリンパ浮腫・リンパ囊胞子防における 優位性を示唆すると思われる。しかしながら、こ れらの報告では、超音波検查やCT等を用いた詳 細なリンパ霊胞の検索は行われておらず、症候性
の合併症についてのみ言及されている。さらに、 上記を含む諸外国での検討・報告の場合、術後管 理は手術を行った施設で行われていない場合も多 く、長期間のフォローアップは困難である。 Solberg $~^{13)}$ は前立腺癌症例に対する骨盤リンパ 節郭清について検討し、術後のCTにて開腹群で は61\%、腹腔鏡群では $37 \%$ リンパ襄胞を認める が、多くは無症候性であったとしている。 Freid $^{14)}$ らも同様に腹腔鏡下リンパ節郭清後に $30 \%$ 程度のリンパ囊胞形成を報告しているが、臨 床症状を示すものは $3.5 \%$ と低率であった。以上 より、腹腔鏡下リンパ郭清は臨床症状を示すリン パ浮腫・リンパ囊胞を抑制するが、潜在的に無症 候性のリンパ囊胞を生じているものと考えられ、 今回われわれの試みた手法は長期的なリンパ系の 合併症をさらに減じる可能性があるものと思われ た。

骨盤腹膜無縫合による骨盤リンパ囊胞の子防は 古くから行われている試みであるが、その有効性 に対する評価は施設により様々である。初期の報 告ではリンパ囊胞を隇ずるとするものが多かった が15)、その後のprospective-randomized trialでは、 腹膜縫合の有無のみでリンパ囊胞形成の率は変わ らない ${ }^{16)}$ とするものもある。超音波検査やCT等 を用いた詳細な検討では、腹膜無縫合により後腹 膜腔を開放しても16２5\%(うち症候性 3〜 7\%) 程度のリンパ囊胞の発生が認められるようであ $ろ^{1,16)}$ が、腹膜縫合を行った場合の、時に50\%以 上に及ぶとされる発生率よりは低いと考えられ る ${ }^{12)}$ 。いずれの報告においても、腹膜無縫合によ る合併症の増加は認められていない。以上の検討 はすべて開腹症例に対して行われており、腹腔鏡 下手術の場合は、ほとんどの施設で骨盤腹膜は無 縫合処理されているため同様の比較は行われてい ない。しかし、腹腔鏡下リンパ節郭清で症候性の リンパ囊胞が減少する理由の一つに後腹膜腔の開 放が関連している可能性はあるものと推測される。

フィブリン糊使用によるリンパ浮腫並びにリン パ襄胞の発症予防の成績は、婦人科領域以外も含 め、その評価は様々である。フィブリン糊使用に より、術後のドレーン排液量の減少とドレーン留 置日数の短縮が認められ入院日数の短縮が可能で あったとするものもあれば(2)、全く無効とする報 告 ${ }^{21)}$ 、反対にドレーン排液量を増やすという報告 もある ${ }^{22,23)}$ 。またリンパ浮腫、リンパ囊胞の減少 に効果が期待できるとする報告もあれば有意差を 認めないとするもの様々である。今回の検討では、 
多くの症例で一過性の腹水増加が観察され、一部 に腹部膨満感を訴える症例も認められた。 Benedetti-Paniciらによる開腹による骨盤腹膜無 縫合術式の検討 ${ }^{1)}$ でも 18 35\%の症例で腹腔内の 液体貯留が報告されている。このような腹水貯留 は骨艋腹膜縫合時には認められないため ${ }^{24)}$ 、これ らの腹腔内の液体はおそらくリンパ組織由来のも のと考えられる。後腹膜腔からの産生と腹膜から の再吸収の不均衡が生ずるリンパ液の貯留が、術 後早期にはこのような腹水の増加として観察され るものと推測された。今回の検討では、全症例に フィブリン糊を使用しているため、フィブリン糊 が腹水貯留と関連しているかについては判断が困 難であるが、少なくともリンパ管断端の接着効果 によりリンパ液洷出が強力に抑制されているわけ ではないと考えられた。

当科では現在、開腹によるリンパ節郭清術施行 時にも腹膜無縫合法とフィブリン糊噴霧を併用し ているが、フィブリン糊を併用していなかった期 間の開腹症例と比較すると、術後のリンパ浮腫 • リンパ囊胞・イレウスの発症は少ない傾向にある (未発表デー夕)。一方、開腹でフィブリン糊を併 用している場合の術後の腹水貯留量は明らかに少 なく、ドレーン抜去までの術後平均日数は腹腔鏡 下手術例とほぼ同じであった。この違いの原因と して、腹腔鏡下でのリンパ節郭清手技またはリン パ管断端処理に不十分な点がある可能性は否定で きない。特に頭側の断端処理に関しては、可及的

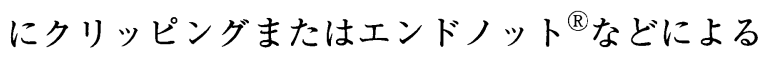
結紮を行っているが、乳糜腹水を認めた 1 例の経 験もあり、完全に開腹術と同程度に処理されてい なのかもしれない。しかし、この1例を除くと術 後の腹水貯留は一時的なものであり、外来での観 察期間中に全例で腹水減少が確認され、治療が必 要な症例は経験されなかった。すなわち手術直後 には後腹膜腔からのリンパ液の産生と腹膜からの 再吸収の不均衡が生じ多量の腹水として観察され るものの、後腹膜腔の完全な腹腔化によってリン パ裹胞の形成は抑制され、骨盤腹膜の再生、リン パ管側副路の発達とともにリンパ液の産生／再吸 収のシフトが生じて最終的に腹水量は正常化し、 定常状態に復帰するものと考えられる。

\section{結＼cjkstart語}

腹腔鏡下リンパ節郭清施行時に大量の希釈した フィブリン糊を使用することで、リンパ浮腫並び にリンパ襄胞の発症を予防できる可能性が示唆さ
れた。本法の施行により早期のドレーン抜去が可 能となり、術後入院日数の短縮が期待され、さら なるQOL改善の可能性があると考えられた。今 後は、さらに症例数を増やし、観察期間を延長し て検討したい。

本論文の要旨は第45回日本産科婦人科内視鏡学 会において発表した。

\section{文 献}

1 ) Benedetti-Panici P, Maneschi F, Cutillo G, et al. A randomized study comparing retroperitoneal drainage with no drainage after lymphadenectomy in gynecologic malignancies. Gynecol Oncol 65: 478-482, 1997.

2) Yamamoto R, Saitoh T, Kusaka T, et al. Prevention of lymphocyst formation following systematic lymphadenectomy. Jpn J Clin Oncol 30: 397-400, 2000.

3 ) Querleu D, Leblanc E, Castelain B. Laparoscopic pelvic lymphadenectomy in the staging of early carcinoma of the cervix. Am J Obstet Gynecol 164: 579-581, 1991.

4) Nezhat CR, Nezhat FR, Burrell MO, et al.Laparoscopic radical hysterectomy and laparoscopically assisted vaginal radical hysterectomy with pelvic and paraaortic node dissection. J Gynecol Surg 9: 105-120, 1993.

5 ) Steed H, Rosen B, Murphy J, et al. A comparison of laparascopic-assisted radical vaginal hysterectomy and radical abdominal hysterectomy in the treatment of cervical cancer. Gynecol Oncol 93: 588-593, 2004.

6 ) Kohler C, Klemm P, Schau A, et al. Introduction of transperitoneal lymphadenectomy in a gynecologic oncology center: analysis of 650 laparoscopic pelvic and/or paraaortic transperitoneal lymphadenectomies. Gynecol Oncol 95: 52-61, 2004.

7 ) Jackson KS, Das N, Naik R, et al. Laparoscopically assisted radical vaginal hysterectomy vs. radical abdominal hysterectomy for cervical cancer: a match controlled study. Gynecol Oncol 95: 655-661, 2004.

8 ) Tozzi R, Malur S, Koehler C, et al. Laparoscopy versus laparotomy in endometrial cancer: first analysis of survival of a randomized prospective study. J Minim Invasive Gynecol 12: 130-136, 2005.

9 ) 安藤正明, 伊熊健一郎, 土岐利彦. 婦人科腹腔鏡下 手術の実際 9. 婦人科悪性疾患に対する後腹膜リン 八゚節郭清. 産婦人科治療 89: 455-463, 2004.

10) Spirtos NM, Eisenkop SM, et al. Laparoscopic radical hysterectomy (type III) with aortic and pelvic lymphadenectomy in patients with stage I 
cervical cancer: surgical morbidity and intermediate follow-up. Am J Obstet Gynecol 187: 340348, 2002.

11) Nezhat F, Yadav J, Rahaman J, et al. Laparoscopic lymphadenectomy for gynecologic malignancies using ultrasonically activated shears: analysis of first 100 cases. Gynecol Oncol 97: 813-819, 2005.

12) Suzuki M, Ohwada M, Sato I. Pelvic lymphocysts following retroperitoneal lymphadenectomy: retroperitoneal partial "no-closure" for ovarian and endometrial cancers. J Surg Oncol 68: 149152, 1998.

13) Solberg A, Angelsen A, Bergan U, et al. Frequency of lymphoceles after open and laparoscopic pelvic lymph node dissection in patients with prostate cancer. Scand J Urol Nephrol 37: 218-221, 2003

14) Freid RM, Siegel D, Smith AD, et al. Lymphoceles after laparoscopic pelvic node dissection. Urology 51(5A Suppl): 131-134, 1998.

15）永田一郎、星原孝幸. 単純、準広汎、広汎子宮全 摘術における骨盤腹膜無縫合法. 産婦人科治療 63 : 337-344, 1991.

16) Franchi M, Ghezzi F, Zanaboni F, et al. Nonclosure of peritoneum at radical abdominal hysterectomy and pelvic node dissection: a randomized study. Obstet Gynecol 90: 622-627, 1997.

17) Lopes AD, Hall JR, Monaghan JM. Drainage following radical hysterectomy and pelvic lymphadenectomy: dogma or need? Obstet Gynecol 86: 960-963, 1995.

18) Petru E, Tamussino K, Lahousen $M$, et al. Pelvic and paraaortic lymphocysts after radical surgery because of cervical and ovarian cancer. Am J Obstet Gynecol 161: 937-941, 1989.

19) Sonoda Y, Leblanc E, Querleu D, Castelain B, Papageorgiou TH, Lambaudie E, Narducci F.Prospective evaluation of surgical staging of advanced cervical cancer via a laparoscopic extraperitoneal approach.

Gynecol Oncol 91: 326-331, 2003.

20) Moore M, Burak WE Jr, Nelson E, Kearney T, Simmons R, Mayers L, Spotnitz WD. Fibrin sealant reduces the duration and amount of fluid drainage after axillary dissection: a randomized prospective clinical trial. J Am Coll Surg 192:591599, 2001.

21) Scholz HS, Petru E, Benedicic C, et al. Fibrin application for preventing lymphocysts after retroperitoneal lymphadenectomy in patients with gynecologic malignancies. Gynecol Oncol 84: 43-46, 2002.

22) Tachibana M, Kinugasa S, Yoshimura H, et al.
Does fibrin glue reduce lymph leakage (pleural effusion) after extended esophagectomy? Prospective randomized clinical trial. World J Surg 27: 776-781, 2003.

23) Dinsmore RC, Harris JA, Gustafson RJ. Effect of fibrin glue on lymphatic drainage after modified radical mastectomy: a prospective randomized trial.

Am Surg 66: 982-985, 2000.

24) Conte M, Panici PB, Guariglia L, et al. Pelvic lymphocele following radical para-aortic and pelvic lymphadenectomy for cervical carcinoma: incidence rate and percutaneous management. Obstet Gynecol 76: 268-271, 1990. 